\title{
Determinants of Labor-Intensive Exports by the Developing Countries: A Cross Country Analysis
}

\author{
Mottaleb Khondoker \\ International Rice Research Institute, Manila \\ and \\ Kaliappa Kalirajan \\ Crawford School of Public Policy \\ The Australian National University
}




\title{
Determinants of Labor-Intensive Exports by the Developing Countries: A Cross Country Analysis
}

\begin{abstract}
While it is widely recognized that industrial development is imperative in developing countries to reduce poverty and to attain sustainable economic growth, there is no consensus on how to develop industries and where to start. Generally, the literature argues that developing countries should concentrate on promoting labour intensive industries and exports first due to their low capital stock and relatively abundant labor force. Though many developing countries are attempting to follow this path, the interesting observation is that not all developing countries are reaping the benefits of promoting labor intensive industries in terms of employment generation and sustaining economic growth. This raises an important question as to how it is possible for some developing countries to enjoy more benefits from labor intensive industries, while others are not able to do so. Using cross-country panel data in explaining heterogeneous performance in exporting labor intensive products by the developing countries, an attempt has been made in this paper to identify the important factors over and above the conventional factors such as low labor wages that contribute to the sustained growth of labor intensive exports from developing countries. The empirical findings of this paper emphasizes that even to initiate and sustain the growth of the low value added industries, such as garments, the developing countries should develop basic infrastructure and maintain a friendly business environment.
\end{abstract}

Key words: Developing Country, Garment and textile export, Infrastructure, Business environment, ASIA, Sub-Saharan Africa.

JEL Classification: L67, F14, O14 
According to the World Bank (2010), around 1.4 billion people in the world are extremely poor, living on less than US\$1.25 per day, and the majority of these extremely poor people resided in South Asia and Sub-Saharan Africa. The eradication of extreme poverty is a major focus in the development policy agenda in these regions. The question is how to eradicate extreme poverty in these regions? It is widely recognized that industrial development in developing countries is imperative to reduce poverty and to attain sustainable economic growth (e.g., Mottaleb and Sonobe, 2010, Sonobe and Otsuka, 2011). Particularly important is the development of export-oriented labor industries, because the development of exportoriented labor-intensive industries would not only create enormous income and employment opportunities for the poor in the labor abundant developing countries (e.g., Mottaleb and Sonobe, 2010, Nam et al.,, 2010; Hayami, 1998; Hayami et al., 1998; Sonobe and Otsuka, 2011, Schimitz and Nadvi, 1999; Nadvi, 1994), but also would facilitate the absorption of advanced skills and know-how through exports to advanced countries (e.g., Gereffi, 1999, Schimitz and Knorringa, 2000).

In fact, the last two decades of the twentieth century witnessed the emergence of a few rapidly growing developing countries, most of which have been propelled by export-oriented industries such as, garment, textiles and toys that are highly labor-intensive in nature. For example, Bangladesh, Vietnam, China and India are some of the steadily growing developing countries in the world, which have emerged as major garment and textiles exporters (e.g., Gereffi, 1999; Joshi, 2002, Nam et al., 2010). The availability of the cheap labor in these developing countries may provide a comparative advantage in producing and exporting laborintensive products as explained by the Hecksher-Ohlin's factor endowment theory. However, the interesting reality is that not all developing countries are equally successful in reaping the benefits cited in the literature from developing labor-intensive industries and exporting labor intensive manufacturing products. An important empirical question is as to what determines the success of the developing labor-intensive industries and exports of labor intensive products by the developing countries over and above the conventional factors such as low wages?

While a large number of studies are available on the role of exports on overall economic growth (e.g., Salvatore and Hatcher, 1991; Moschos, 1989; Krueger, 1980), few studies directly examine the determinants of the success of exports, particularly the labor-intensive 
exports by the low-income developing countries. Using information from four countries in Asia, Dollar, Hallward-Driemeier and Mengistae (2005) demonstrate that business environment and infrastructure critically affect the growth of the labor-intensive garment industry and garment exports by developing countries. A study that uses a more direct approach to examine the determinants of labor-intensive exports by the developing countries was done by Ninkovic (2009). Using cross country panel data, she empirically demonstrates that besides labor and capital, home countries' transport infrastructure, as well as transportation costs, critically determine the labor-intensive exports by the developing countries. Ninkovic's (2009) study, however, has several limitations. For example, she does not focus solely on the developing countries. Instead, data was pooled across a number of middle (e.g., Malaysia) and low-income countries (e.g., Bangladesh), and across a number of seemingly labor-intensive products (e.g., garment, textile, printing) even without any control for countries' income status and industry. Secondly, Ninkovic (2009) has pooled across data over 28 years (1976 to 2004) without considering any structural changes during that long time period such as, the removal of garment export quota system under the Multi Fiber Agreement (MFA) in 1995. The above arguments indicate the need for more empirical studies to investigate the factors that facilitate or hinder the development of labor-intensive industries in the developing countries.

In this context, the objective of this paper, using information on labor-intensive garment exports by 65 developing countries from Asia, Africa, Latin America and Europe during 2003 to 2007, is to identify the factors that affect the labor-intensive and export-oriented industrial development in the developing countries. We use garment exports by the sampled developing countries as a case, because garment industry has been identified as a typical 'starter industry', as many of the presently developed countries, such as USA, UK, and Japan started their industrial development through the garment industry (Zakim, 1999; Gereffi, 1999, Yamagata, 2007). The newly industrialized countries (NICs) of Hong Kong, South Korea, Taiwan and Singapore had also started industrial development through the exportoriented garment industry. Presently, while the garment export is dominated mostly by a few developing countries such as, China, Bangladesh, India and Vietnam, the performance varies greatly among the developing countries. Importantly, countries in Sub-Saharan Africa, which are heavily stricken by extreme poverty, are given favorable market access to USA under the African Growth and Opportunity Act (AGOA) 2000. However, presently the export performance of these countries is still relatively poor. It is important to identify what should 
be done by the low performing countries, particularly by the poverty stricken African countries to exploit the full benefit of the development of export-oriented labor intensive industries in the presence of the favorable access to the major markets.

In this paper, we empirically demonstrate that in addition to the availability of labor, the availability of fixed capital, basic infrastructure, transportation costs, and, above all, a business friendly environment significantly contribute to the development of export-oriented garment industries in the developing countries. The finding is robust, because the major empirical findings do not change even after the exclusion of some the control variables during the sensitivity tests. While it is acknowledged that these factors are equally important for almost all industrial sectors including agricultural processing, contrary to the general perception by the policymakers that low labor wages are the main determinant of the growth of the labor intensive industries, the analysis in this paper emphasizes that even to initiate less sophisticated ordinary industries, such as garments, the poverty stricken developing countries need to develop and invest on basic infrastructure and maintain a friendly business environment.

The rest of the paper is organized as follows. Section 2 presents a brief literature review addressing a stylized fact related to the emergence of garment industry in low-income countries, and also presents a comparative analysis on the performance of the developing countries in garment and textiles exports. Section 3 presents data sources, theoretical background, and an empirical model that we use in this paper. Regression analyses and findings are presented in Section 4 followed by conclusion and policy implications in Section 5.

\subsection{Relocation of Export Oriented Garment Industry from Developed to Developing Countries: A Stylized Fact}

According to Vernon's (1966) product life cycle theory, it is usually the developed countries that introduce new products in the market, as the result of their supremacy in scientific innovation and research. Once the technology becomes standardized for the newly introduced product, the production base gradually shifts to other countries mainly to slice down the production and marketing costs. The garment industry is the typical industry that has been relocating from the developed to developing countries in the way that the product life cycle theory predicts. 
Historically, a number of the presently developed countries, for example, UK, USA and Japan started their industrialization process first through the development of garment industry (e.g., Gelb, 2007; Zakim 1999; Yamagata, 2007). Zakim (1999) articulated that organized garment factories emerged in England in the $18^{\text {th }}$ century, and later in the $1850 \mathrm{~s}$ in the USA. During the 1850s, for example, the garment industry was the largest manufacturing industry in New York, where more than 400 garment entrepreneurs were engaged in producing garments (Zakim, 1999). In the 1950s, the garment industry developed in Japan, and in the 1960s the country became the largest exporter of garment in the USA.

In the 1970s, the garment industry gradually developed in the East Asian countries, and by the end of the decade, Hong Kong, Korea, Taiwan and Singapore, presently known as the newly industrialized countries (NICs), emerged as prominent global garment exporters. Finally, since the 1980s, the industry has been gradually developing in other Asian and Latin American countries, and presently some developing countries such as, China, India, Bangladesh, and Vietnam have emerged as the major garment exporters. Thus, historically the garment industry has been migrating from the high-income countries to the low-income countries, while playing a critical role on the early stage of industrial development process in the host economies. Observing its critical role on the industrial development process, Gereffi (1999) refers the garment industry as the "typical starter industry".

The high dependence on cheap labor is one of the important reasons behind the gradual migration of the garment industry from the high income to low-income countries. The garment industry is highly labor-intensive, and, thus, highly sensitive to the wage rates. Generally, wage rate tends to be relatively lower in the developing countries. As garment industry is highly labor-intensive industry, developing countries tend to enjoy a comparative advantage in producing garment and textiles. As industrialization proceeds, wage rate increases, the comparative advantage in producing the labor-intensive products may be lost eventually. Yamamura et al., (2003) clearly depicted the evolution and relocation patterns of the garment industry in Japan, in which, a sharp increase in the wage rate due to the rapid industrialization in the 1970s forced the Japanese garment entrepreneurs to relocate their production base firstly from the urban to rural areas within Japan, and, finally, from Japan to China and other East Asian countries, mainly to cut down the wage costs. Thus, in general the labor-abundant developing countries tend to be successful in exporting the labor-intensive garment and textiles products compared to the high-income countries. 
Figure 1 inserted to be here

Figure 1 clearly demonstrates that fact. In the vertical axis of figure 1 , we plot the natural log of garment export by 78 countries to the USA in 2007 . We only consider the countries that have exported at least US\$2000 of garment to the USA in 2007. In the horizontal axis we plot the natural log of per capita GDP of 78 countries measured in current US dollar in 2007. The fitted line in figure 1 is estimated based on a polynomial functional form. The inverted ushaped fitted line confirms the stylized fact that while developing countries with relatively low per capita income are in advantageous position in exporting garments, with the increase in per capita income, a country gradually losses it comparative advantage of exporting labor intensive products which is garment in this case.

\subsection{The performance of Developing Countries in Exporting Garment and Textiles Varies Greatly}

As Figure 1 reveals, the developing countries are in fact dominating the labor-intensive garment and textile exports. Interestingly, while the developing countries dominate the garment and textile exports in the world, not all of the developing countries endowed with relatively cheap labor have been equally successful in exporting highly labor-intensive garment and textiles. For example, according to World Trade Organization's (WTO) trade statistics, in 2007, the total exports of garment and textiles in the world was US\$ 588.39 billion. Bangladesh, a low-income country from South Asia, exported nearly 10.0 billion in 2007 that accounted for 1.66 percent of the world's exports. In the same year, the sum of the total garment and textiles exports by 30 low-income Sub-Saharan African countries were even less than one-tenth of Bangladesh's exports (WTO, 2010). Table 1 clearly presents the fact.

Table 1 presents information on the garment and textiles exports and their shares in total export earnings of the sampled 65 sampled developing countries. The data on the garment export in Table 1 were extracted from the official websites of the USA and the EU. Name of the sampled countries and their geographical position can be seen in Table A1 and details and about the data sources can be seen in Table A2. An export of garment and textiles by a country is constructed as the sum of exports by a country to EU and USA. We only consider the exports of HS code 61 that includes the woven garment export, and HS code 62 that include the knitwear garment export. The data on the textiles exports were extracted from the online data base of the World Trade Organization. 
Table 1 to be inserted here

In Table 1, we have divided the sampled countries into four groups based on their geographical locations. The first group consists of 13 countries located in South and East Asia. The second group consists of seven countries located in Central Asia. The third group consists of 30 countries from Sub-Saharan Africa. The fourth group consists of 14 countries, in which seven countries are from Latin America, three are from Europe and rests are from North Africa. Table 1 shows that the South and East Asian countries are the top exporters of garment and textiles compared to all other countries across the region. It shows that on average, in 2007, countries from South and East Asia regions exported US\$ 5,440 million of garments and US\$ 6,080 million of textiles. On average, the sum of the exports of the garment and textiles comprises more than seven percent of the total export earnings of a country in South and East Asia. The second largest exporters are the countries from Latin America, Europe and North Africa, in which, the average garment and textile exports by a country was US\$ 750 million and US\$ 180 respectively. The table vividly demonstrates that compared to all other regions, countries in Sub-Saharan African region are relatively poor performer in exporting garments and textile, despite they are given a favorable market access to USA under the African Growth and Opportunity Act (AGOA) 2000. Thus, the performance of the developing countries in garment and textile export is highly heterogeneous.

Even among the top performing labor intensive export earners, the determinants of labor intensive industries vary significantly. For example, it is commonly known that China is the number one exporter of labor intensive goods and India, which has the second largest population very close to China, is not able to perform like China with respect to labor intensive exports. Interestingly, India has certain characteristics such as well organized legal system, well protected intellectual property rights, and no language barrier, which are lacking in China. The labor force in India is at least as productive as in China. Nevertheless, the growth of labor intensive industries and exports is tremendous in China, which raises an important question about the differences in country characteristics between China and India. Sud (2005) argues that China offers business friendly environment, less bureaucratic procedures and that physical infrastructure including power availability is much superior to India. Thus, the inferences is that not all policymakers in developing countries believe that providing business friendly environment and good physical infrastructure is not at least as important for the growth of the labor intensive industries as they are for the capital intensive industries. 
In the next section, we explain the data sources, define the variables, and develop an empirical model with an aim to identify the factors that may be responsible for the heterogeneous performance in exporting garment and textiles by developing countries.

\subsection{Materials and Method}

\subsection{Data sources and Definition}

This study is based on information on 65 developing countries in 2003 to 2007. Out of 65 sampled developing countries, 13 are from South and East Asia, 10 are from Central Asia, 30 are from Sub-Saharan Africa, seven are from Latin America, three are from Europe and the rest is from North Africa. The name of the sampled countries by group is presented in Table A1 in the Annexure. Among the sampled developing countries, 38 countries are the lowermiddle income countries according to the definition of the World Bank (2009) with per capita gross national income (GNI) ranges between US\$ 996 to US\$ 3,945, and the rests 27 are the low income countries with per capita GNI less than US\$ 996. As we mentioned in the previous section, the data on the garment export by the sampled countries to US and EU were extracted from the official websites of US government and European Commission. Note that as real effective exchange rate (REER) for many of the sampled countries were not available, we converted exports to EU using the nominal exchange rate. We also consulted the World Development Indicators 2009, and the online infrastructure data base of the World Bank (2010), International Financial Statistics, 2009 by International Monetary Fund (2009), the online data sources of Food and Agriculture Organization (FAO), and World Fact Book, the online data base of the Central Intelligence Agency (CIA) of USA for supplementary information on fixed capital, basic infrastructure and public service quality. The details about the data sources are included in Table A2 in the annexure.

To put some light on the probable influential factors that may affect the exports of laborintensive products by the sampled developing countries we develop descriptive Tables 2 and 3.

Table 2 presents information on the factor endowments, such as gross fixed capital, land and labor, and information on some of the crucial basic physical infrastructure in the sampled developing countries in 2007. The gross fixed capital consists of net changes in the level of inventories plus the fixed assets of an economy (World Bank, 2009). The fixed assets include 
improvement of land, plant, machinery, and equipment purchases; and the construction of roads, railways, schools, offices, hospitals, private residential dwellings, and buildings for commercial and industrial uses. The arable land area is defined as land under temporary crops, temporary meadows for mowing or pasture, plus land uses for market and kitchen gardens and temporarily fallow land (FAO, 2010). The total labor force comprises all economically active people, who are 15 years or older either working or unemployed. It shows that on average, the South and East Asian countries are relatively 'land-poor', but 'labor rich' compared to all other sampled countries.

Table 2 to be inserted here

Table 2 shows that the Central Asian and Latin American countries are relatively more endowed with both capital and land. The Sub-Saharan African countries are absolutely poor with capital compared to all other countries; however, they are relatively more labor rich, at least in terms of the absolute number of the workers compared to the Latin American countries. According to Table 2, on average, the total labor force in a Sub-Saharan African country consists of 7.77 million workers. In contrast, on average, the total labor force in a Latin American country consists of only 6.16 million workers. However, as Table 2 shows, the volume of exports of garment and textiles by the sampled Sub-Saharan African countries is much lower than the Latin American countries. Thus, only the availability of labor cannot explain the sharp contrast in the performance of the developing countries in garment and textiles exports.

Table 2 also presents information on basic infrastructure of the sampled countries, such as the electricity consumption per capita, internet users per 100 people, and the total road networks. The electric power consumption per capita measures the total production of power minus the transmission, distribution, and transformation losses divided by the total population. The total road networks include all roads in a country including motorways, highways, and main or national roads and secondary or regional roads. The internet users are the people with access to worldwide network (World Bank, 2009). The table shows that sampled Sub-Saharan African countries are not only 'capital poor', but also relatively poor in basic infrastructure. It shows that on average, a country in Sub-Saharan Africa consumes less than 210 kilowatt hour of electricity in a year per capita, and only three people in one hundred have connected with broad band internet facility. 
In Table 3, we try to depict the overall business environment, and also provide some information on trade costs using some proxy variables such as, days required to start a new business, inflation rate, currency exchange rate, and the distance to USA and EU. The days required starting a business is the number of calendar days needed to complete the procedures to legally operate a business, which can be seen as a proxy of the efficiency of the government, and the overall business environment of a country. Inflation is measured as the annual increase in the general prices. A few studies (e.g., Mottaleb and Kalirajan, 2010) have argued that inflation provides a signal on the health status of a country, where controlled and moderate inflation works as an indicator of a promising economy. The currency exchange rate is the nominal exchange rate between US dollar and local currency.

Table 3 to be inserted here

Table 3 shows that Sub-Saharan African countries require more calendar days compared to all other sampled countries to legally start a new business, probably due to the bureaucratic complexity, and unfriendly business environment. The table also shows that South and East Asian countries, which are the high performers in exporting garment and textiles, enjoy lower inflation rate among the sampled countries. Table 3 shows that Asian garment and textile products are in general relatively cheaper in terms of US dollar compared to all other sampled countries, because of lower exchange rates in terms of US dollar.

Table 3 also presents information related to transportation costs. Table 3 shows that out of 65 sampled developing countries, a total of 16 are landlocked, of which two are in South and East Asia, three are in Central Asia, eight are in Sub-Saharan Africa, and three are in Latin America, North Africa and Europe. Similar to the World Fact book definition, we define countries without a sea coast as a landlocked country. The landlocked countries might face a higher transportation cost in international trade compared to the countries with sea ports. The table also shows that out of 65 sampled developing countries, a total of 38 are the lowermiddle income countries, and the rest 27 are the low-income countries. Importantly, among the sampled 27 low-income countries, of 22 are located in Sub-Saharan Africa, three are in South and East Asia, and rest five are located in Central Asia. In our empirical model, we include the dummies for landlocked and lower-middle income country to observe how these characteristics of a country affect their labor- intensive exports. The last two rows of table 3 
presents the one-way linear airline distances from the sampled countries to New York, the largest city in the USA, and to the capital city of EU that is Brussels, Belgium. The longer is the distance, the higher might be the trade costs, and, thus, it might affect the garment and textile exports negatively. Table 3, however, shows that the average distance to the USA and EU from South and East Asian countries, who are the best performers in garment and textile exports, is higher compared all other sampled countries.

In the next section, we develop an empirical model to identify the determinants of garment and textile exports by the developing countries. Before that we present correlation matrices to demonstrate the one-to-one relationship among garment and textiles exports, and some of the important variables in Table A3 and Table A4 in the annexure.

Table A3 in the annexure shows that all of the correlation coefficients of the variables that represent factor endowments, such as gross fixed capital (FCAP), arable land (ARAL), labor (LAB), and the infrastructure variable such as, electricity consumption per capita (ELEC), internet users per 100 people (INET), and the total road networks (ROAD) are positive and significantly related with garment (GAREX) and textiles (TEX) exports in 2007. Table A4 presents the correlation matrix that presents the coefficient of correlation among garment and textiles exports, and all of the proxies of business environment variables, such as the days required to start a new business (TSTBUSI), consumer price inflation (INFLA), currency exchange rate with US dollar (XRATE), a dummy for the landlocked countries (LALOC), a dummy for the lower-middle income countries, and the distance to New York, USA (DISUSA) and Brussels, Belgium (DISEU). Although the signs of the most of the correlation coefficients are in line with the conventional wisdom and the existing theory, none of them are significant in Table A4. For example, the correlation between days required to start a new business and garment and textile exports are negative, which is intuitive, as the more days required to start a new business, the lower may be the exports due to increase in transaction costs (e.g., Mottaleb and Kalirajan, 2010), however, the relationship is not statistically significant. The correlation coefficients in Table A3 and A4 are, however, present only the one-to-one relationship between variables without considering the effects of other influential variables at the same time. In the next section, we develop an empirical model to isolate the effect of each variable, while considering the impact of other variables at the same with an aim to explaining the observed differences in the export performance of the garment by the developing countries. 


\subsection{Theoretical Background and Empirical Model}

The standard framework used to analyze the pattern of trade by a country is the HecksherOhlin factor endowment theory. According to the theory, relatively labor abundant countries will produce and export labor-intensive goods, and relatively capital-intensive countries will produce and export capital-intensive goods (e.g., Kilpatrick and Miller, 1978). In a symbolic form, it can be written as:

$\log \left(E X^{c}\right)_{i t}=\beta_{0}+\beta_{1} \log \left(\frac{k_{t-1}^{c}}{L_{i t}^{c}}\right)+\beta_{2} \log \left(\frac{L A_{t}^{c}}{L_{i t}^{c}}\right)+\beta_{3} \log \left(L_{i t}^{c}\right)+\xi_{i t}-----(1)$

Where $\mathrm{EX}_{\mathrm{it}}^{\mathrm{c}}$ is the export of labor-intensive products, which is garment in our case, by country $\mathrm{c}$, at time $\mathrm{t}$, and $\mathrm{k}_{\mathrm{t}-1}^{\mathrm{c}}, \mathrm{LA}_{\mathrm{t}}^{\mathrm{c}}, \mathrm{L}_{\mathrm{it}}^{\mathrm{c}}$ stand for the gross fixed capital, arable land, and the total labor force respectively and $\beta$ 's are the variables of interest. $\xi$ is the usual statistical error term. To get the per capita variables, we divided gross fixed capital, and arable land by the total labor force variable. The problem in this model is that in many cases the model has failed to explain why a capital-rich country such as, USA exports labor intensive products, which is the well known Leontief paradox (Leontief, 1968 cited in Kilpatrick and Miller, 1978; Davis et al., 1997). Recent studies also ruled out the utility of Hecksher-Ohlin's model in explaining the international trade pattern (e.g., Trefler and Zhu, 2000; Davis et al., 1997).

To explain the international trade pattern more precisely, the gravity model considers trade costs in addition to the factor endowments of a country (e.g., Limano and Venables, 2001; Anderson and Wyncoop, 2004; Feenstra et al., 2001). Usually, partner country's GDP size is used as a gravity factor, and distance and other variables, such as the non-availability of port facilities as antigravity factors. Considering the gravity-antigravity factors in explaining the international trade pattern, we rewrite equation (1) in the following form:

$$
\begin{aligned}
& \log \left(E X^{c}\right)_{i t}=\beta_{0}+\beta_{1} \log \left(\frac{k_{t-1}^{c}}{L_{i t}^{c}}\right)+\beta_{2} \log \left(\frac{L A_{t}^{c}}{L_{i t}^{c}}\right)+\beta_{3} \log \left(L_{i t}^{c}\right)+\beta_{4} \log \left(D I S U S A^{c}\right)+\beta_{5} \log \left(D I S E U^{c}\right) \\
& +\theta_{i}\left(L A L O C^{c}\right)+\xi_{i t}-----(2)
\end{aligned}
$$

Where DISUSA stands for the distance between a sampled country c to New York, USA, and DISEU stands for the distance to Brussels, Belgium, and LALOC is a dummy that assumes value 1 if a country is landlocked and 0 , otherwise. 
In addition to factor endowment and gravity-antigravity variables, the literature on social infrastructure has long been argued that institution or social infrastructure may significantly affect the overall performance of a country (Knack and Keefer 1995; Acemoglu, Johnson and Robinson, 2001; Dollar and Kraay, 2003). Better business environment allows markets to function properly, thus enhances the business profitability by reducing market failures (e.g., Kinda, 2010; Mottaleb and Kalirajan, 2010). Eifert, Gelbb Ramachandran (2008) empirically demonstrate that the high operation costs of doing business and market failure in developing countries that stem mainly from insufficient infrastructure, inefficient public services, and stringent rules and regulations, all significantly hamper industrial development process in developing countries. Dollar, Halward-Driemeier and Mengistae (2005), particularly identify that the business environment, represented by power outages, delay in getting a telephone connection, and delay in clearing the customs, are the most serious bottlenecks on expansion and growth of labor-intensive industries in developing countries. As we intend to examine the role of business environment and infrastructure in explaining the performance in exporting labor-intensive garment and textiles by the developing countries, we rewrite equation (2) in the following final form:

$$
\begin{aligned}
& \log \left(E X^{c}\right)_{i t}=\beta_{0}+\beta_{1} \log \left(\frac{k_{t-1}^{c}}{L_{i t}^{c}}\right)+\beta_{2} \log \left(\frac{L A_{t}^{c}}{L_{i t}^{c}}\right)+\beta_{3} \log \left(L_{i t}^{c}\right)+\beta_{4} \log \left(\text { DISUSA }^{c}\right)+\beta_{5} \log \left(\text { DISEU }^{c}\right) \\
& +\theta_{i}\left(\text { LALOC }^{c}\right)+\left(\text { INFRA }_{t}^{c}\right) \lambda_{i}+\left(\text { ISUSI }_{t}^{c}\right) \sigma_{i}+\sum_{i=0}^{3} \rho_{i}\left(L D^{c}\right)+\sum_{i=0}^{3} v_{i}(\text { Yeardummies })+\psi_{i}\left(\text { LIC }^{c}\right)+\xi_{i t}--(3)
\end{aligned}
$$

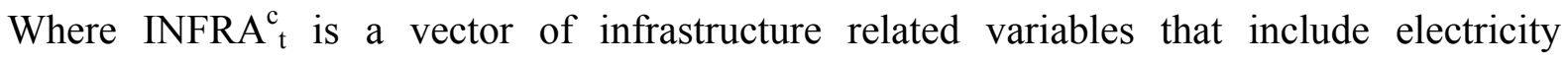
consumption per capita, internet users per 100 people, the total road networks in country c at time $t$, and $\mathrm{BUSI}_{\mathrm{t}}^{\mathrm{c}}$ is a vector of business environment related variables that includes days required to start a new business, consumer price inflation and the local currency exchange rate with US dollar of country c at time t. Additionally, following Dollar, Halward-Driemeier and Mengistae (2005) and to control for unobserved heterogeneity among the sampled countries (in any) we include year dummies where year 2004 is the base year, and location dummies, where South and East Asia is the base, and a dummy for the lower-middle income country (LIC), $\xi$ is the error term with white-noise property.

Application of the pooled OLS estimation method might provide inefficient estimators by providing deflated standard errors, because of the unobserved heterogeneity problem (if any). Therefore, an appropriate estimation technique (either Fixed effect or Random effect 
estimation) will be applied for estimating equation (3). To check the robustness of the findings, we also perform sensitivity analyses by excluding additional control variables stepby-step in the estimation process.

Table 4 presents the estimated models that explain the exports of the garment by the developing countries. Note that we only focus on garment export excluding textile export mainly to avoid the problem of heterogeneity, as textile industry is relatively more capital intensive in nature (e.g., Mottaleb and Sonobe, 2010). We apply the Random Effect Generalized Least Square estimation process, as the Hausman test suggests. We also allow intragroup correlation in standard errors while calculating z-values, which gives more efficient estimates. Finally, following Ninkovic (2009), in the estimation process, to avoid possible simultaneity bias, we have taken a year lag of the per capita fixed capital variable in the empirical model.

\subsection{Estimation Results}

Table 4 presents the estimated function explaining the export of garment by the developing countries. While column 2 in Table 4 presents the full sets of the explanatory variables, in the subsequent columns, we gradually excluded the insignificant control variables from the estimated functions to check the robustness of the major findings.

Table 4 shows that the gross fixed capital per worker and the total labor forces are significant and positive across the estimated model explaining garment exports by the developing countries. The variable arable land per worker is positive, but not significant in the estimated function in Table 4. It reveals the importance of capital accumulation in developing countries even to facilitate the development of less sophisticated labor-intensive industries and exports such as garments.

Among infrastructure variables, the electricity consumption per capita is significant and positive across the models explaining the garment export in Table 4. The coefficient of the total road networks is positive but insignificant across the estimated function in Table 4but not significant. The coefficient of internet user per 100 people is appeared as negative and insignificant. A plausible explanation might be that because of a strong correlation with gross fixed capital, the coefficient of road networks, and internet users are not significant both in 
Table 4. The days required to start a business is negative and significant across the estimated functions in Table 4. Based on Table 4, a one percent reduction in the days required to start a new business in a developing country enhances garment exports by 0.54 to 0.64 percent on average. Overall, the findings in Table 4 demonstrate the importance of business environment in developing countries to enhance labor-intensive garment exports.

Among the trade cost variables, the dummy for a landlocked country is negative and highly significant across the estimated models explaining the garment export in Table 4. It shows that on average a landlocked country exports garments 2.30 to 2.40 percent lower compared to a country with a sea coast. It thus supports the argument that international trade is significantly affected by trade costs, where countries with port facilities enjoy the benefit of the lower transportation costs. Estimated models in Table 4 show that the distance to USA and EU negatively affect the garment export by the developing countries. It means countries that locate relatively far from EU and the USA, are in a disadvantageous position compared to countries that are located relatively nearer. However, the coefficients are insignificant in most of the cases in the estimated functions in Table 4. Among other dummies, the lower middle income country dummy, and Sub-Saharan Africa dummy are highly statistically significant and negative in the estimated models explaining the garment exports by the developing countries in Table 4 . On average, a lower-middle income country exports garment 1.80 percent to 2.06 percent less compared to a low-income country. As the lower-middle income countries are relatively capital rich compared to the low-income countries, they face relative low comparative advantage in exporting highly labor intensive garment products relative to the low income countries. As a result, the dummy for a lower-middle income country is highly significant and negative in the estimated models explaining the garment exports in Table 4. Our findings support the real world scenario, for example, although Bangladesh, a low-income country, is a champion garment exporter in the world, mostly depends on imported textiles from China and India, two of the lower-middle income countries (Mottaleb and Sonobe, 2010).

Table 4 to be inserted here 
The findings in Tables 4 support the arguments of Eifert, Gelbb and Ramachandran (2008) that the cost of doing business in developing countries particularly in Sub-Saharan Africa is high due to the unfriendly business environment, insufficient infrastructure, and insufficient and ineffective public services, which in turn hamper the industrial development process. We have empirically demonstrated that the countries that ensure basic infrastructure, such as electricity, and provide a friendly business environment, are more likely to be successful in garment exports. Our findings are also analogous to the findings of Mottaleb and Kalirajan (2010), Kinda (2010) and Kimura and Todo (2010), who demonstrate that business environment and infrastructure significantly affect the decision of foreign investors to invest in a developing country. Our findings also resembles Dollar, Hallward-Driemeier and Mengistae's (2005) findings, who demonstrate that business environment measured by power outages, public service quality, and infrastructure significantly affect the growth of the garment industry in Pakistan, India, Bangladesh and China. Finally, against the findings of Brown, Earle and Lup (2005), our results strongly demonstrate the importance of business environment on labor intensive exports by the developing countries.

The last few rows in Tables 4 present information on overall R-squared, number of the sampled countries, the result of the Hausman test on Fixed effect over Random effect estimation process and the test statistics of endogenity test of the variable per capita electricity consumption. Table 4 shows that the explanatory power of the empirical model is more than 60 percent, and Hausman test statistics suggests using Random effect model over the Fixed Effect estimation method. Importantly, the test statistics also clearly demonstrate the statistical erogeneity of the per capita electricity consumption variable in the estimated functions in Table 4 (see Wooldridge, 2009 for the procedure).

\subsection{Conclusion and Policy Implications}

Rapid industrial development is imperative to eradicate extreme poverty from South Asia and Africa; however there is no consensus on how to develop industries (e.g., Lin and Chang, 2009). Importantly, despite the fact that the poverty stricken Sub-Saharan African countries are given favorable market access to USA since 2000, the overall progress in industrial development and exports are relatively poor compared to other developing countries, such as India, China and Vietnam. It is important to understand what should be done in the low 
performing developing regions to revitalize industrial development in order to attain sustainable growth and to reduce poverty. Using highly labor intensive garment exports, which are labor-intensive, by the developing countries during 2005 to 2007 as a case study, this paper identifies the factors that contribute to the differential growth performance across developing countries.

The general perception by the policymakers is that the growth of the labor intensive industries, which are sometimes in the informal sector, mainly depends on low labor wages and not much on other factors such as basic infrastructure and business friendly environment that are very essential for capital intensive industries. This paper demonstrates that in addition to the availability of cheap labor, the accumulation of capital, basic infrastructure, and business friendly environment are important to facilitate the development and the exports of labor-intensive garment industries by the developing countries. Particularly, the paper empirically demonstrates that the availability of capital and infrastructure are critically important to enhance the labor-intensive garment export by developing countries. The paper also empirically demonstrates that the quality of public services that critically affect business environment of a country is also equally important to facilitate industrial development and exports. Finally, the paper demonstrates that Sub-Saharan African countries and the landlocked countries are in a disadvantageous position in exporting labor-intensive products despite they are endowed with relatively cheap labor.

We, thus, conclude that only favorable market access for the developing countries to the developed countries' market, such as AGOA for the Sub-Saharan African countries, might not be sufficient enough to boost up industrial development process in the poverty-stricken developing countries. In addition to the favorable market access to the developed countries, international donor agencies should invest to develop basic physical infrastructure such as, roads, highways and electricity in developing countries. These basic development inputs may not only facilitate the export-oriented labor intensive industries, but also may facilitate the developing counties to switch from producing and exporting low-value added items to relatively high value items, which is instrumental to poverty alleviation and sustainable economic growth. 


\section{References}

Acemoglu, Daron, Simon Johnson and James A. Robinson. 2001. "The Colonial Origins of Comparative Development: An Empirical Investigation”, American Economic Review, Vol. 91(5):1369-1401.

Anderson, James., and Wincoop, Eric Van. 2004. "Trade Costs. Journal of Economic Literature, Vol. 42(3): 691-751.

African Growth and Opportunity Act (AGOA). Trade and Development Act of 2000. Online: http://www.agoa.gov/, accessed on March 11, 2011.

Brown, David J., Earle, John S. and Lup, Dana. 2005. "What Makes Small Firms Growth? Finance, Human Capital, Technical Assistance, and the Business Environment in Romania", World Development, Vol. 54(1): 33-70.

Central Intellegance Agency (CIA). The World Factbook. Online: https://www.cia.gov/library/publications/the-world-factbook/, accessed on: January 30, 2011$04-24$

Davis, Donald R., David E. Weinsteign, Scott C. Bradford. Kazushige Shimpo. 1997. "Using International and Japanese Regional Data to Determine When the Factor Abundance Theory of Trade Works", American Economic Review, Vol. 87(3): 421-46.

Dollar, David and Kraay, Aart. 2003. "Institutions, Trade and Growth", Journal of Monetary Economics, Vol. 50(1): 1369-1401.

Dollar, David, Hallward-Driemeier, Mary and Mengistae, Taye. 2005. "Investment Climate and Firm Performance in Developing Economies", Economic Development and Cultural Change, Vol. 54(1): 1-31.

Eifert, Benn, Gelb, Alan and Ramachandran, Vijaya (2008). "The Cost of Doing Business in Africa: Evidence from the Enterprise Survey Data”, World Development, Vol. 36(9) 1531-46.

EUROSTAT. 2010. Official Website of the European Commission on Statistics. Online: http://epp.eurostat.ec.europa.eu/portal/page/portal/eurostat/home. Accessed on January 30, 2011.

Food and Agriculture Organization (FAO). 2011. FAOSTAT. Online: http://faostat.fao.org/site/377/default.aspx\#ancor, accessed on: January 30, 2011.

Feenstra, R., Markusen, J., and Rose, A,. 2001. "Using the Gravity Equation to Differentiate Among Alternative Theories of Trade", Canadian Journal of Economics, Vol. 38(2): 430-47.

Gelb, Bernard A. 2007. "CRS Report for Congress: Textiles and Apparel Trade Issues". Prepared for the Members and Committee of Congress. Washington D.C.: Congressional Research Service. Online: http://ncseonline.org/nle/crsreports/economics/econ-134.cfm, accessed on March 04, 2011.

Gereffi, Gary. 1999. "International Trade and Industrial Upgrading in the Apparel Commodity Chain”, Journal of International Economics, Vol. 48(1): 37-70.

Hayami, Y. 1998. "Toward an Alternative Path of Economic Development: An Introduction", in Hayami, Y. (ed.), Toward the Rural-Based Development of Commerce and Industry: Selected Experience from East Asia. Washington: World Bank Economic Development Institute, Washington D.C. 
Hayami, Y., Kikuchi, M., and Marchiano, E. 1998. "Structure of Rural-Based Industrialization: Metal Crafts Manufacturing on the Outskirts of Greater Manila, the Philippines." Developing Economies, Vol., 36(2): 132-54.

International Monetary Fund (IMF). 2009. International Financial Statistics, 2009. CD ROM Version: International Monetary Fund, Washington D.C.

Joshi, Gopal (ed). 2002. Garment Industry in South Asia Rags or Riches? Competitiveness, Productivity and Job Quality in the Post-MFA Environment. New Delhi: International Labor Organization, South Asia Multidisciplinary Advisory Team.

Kilpatrick, John A. and and Miller, Robert R. 1978. "Determinants of the Commodity Composition of U.S. Trade: A Discriminant Analysis Approach”, Journal of International Business Studies, Vol. 9(1): 25-32.

Kimura, Hidemi and Todo, Yasuyuki, 2010. "Is Foreign Aid is a Vanguard of Foreign Direct Investment? A Gravity-Equation Approach” World Development, Vol., 38(4): 482-97.

Kinda, Tidiane. 2010. "Investment Climate and FDI in Developing Countries: Firm Level Evidence", World Development, Vol., 38(4): 498-513.

Knack, Steven and Keefer, Philip. 1995. "Institutions and Economic Performance: Cross- Country Tests Using Alternative Measures”, Economics and Politics, Vol. 7(3): 207-227.

Krueger, Anne. 1980. "Trade Policy as an Input to Development”, American Economic Review Papers and Proceedings, Vol., 70(2): 288-92.

Leontief, W. 1954. "Factor Proportions and the Structure of American Trade: Further Theoretical and Empirical Analysis", Journal of Economics and Statistics, Vol.38(4): 386-407.

Limano, N., and Venables, A. 2001. "Infrastructure, Geographical Disadvantage, Transportation Costs and Trade", World Bank Economic Review, Vol. 15(3): 451-79.

Lin, Justin and Chang, Ha-Joon. 2009. "Should Industrial Policy in Developing Countries Conform to Comparative Advantage or Defy it? A Debate Between Justin Lin and Ha-Joon Chang", Development Policy Review, Vol. 27(5): 483-502.

Moschos, Demetrios. 1989. "Export Expansion, growth and the Level of Economic Development", Journal of Development Economics, Vol., 30(1): 93-102.

Mottaleb, Kh. A., and Kalirajan, Kaliappa. 2010. "Determinants of Foreign Direct Investment in Developing Countries: A Comparative Analysis", Margin- The Journal of Applied Economic Research, Vol. 4(4): 369-404.

Mottaleb, Kh. A., and Sonobe, Tetsushi. 2010. "An Inquiry into the Rapid Growth of the Garment Industry in Bangladesh", Economic Development and Cultural Change, Vol. 60, No. 1: 6789.

Nadvi, Khalid. 1999. "Collective Efficiency and Collective Failure: The Response of the Sialkot Surgical Instrument Cluster to Global Quality Pressure”. World Development, Vol. 27, No.9:1605-29.

Nam, Vu Hoang \& Tetsushi Sonobe and Keijiro Otsuka. 2010. "An Inquiry into the Development Process of Village Industries: The Case of a Knitwear Cluster in Northern Vietnam", Journal of Development Studies, Vol. 46(2): 312-30.

Nam, Vu Hoang \& Tetsushi Sonobe and Keijiro Otsuka. 2009. "An inquiry into the transformation process of village-based industrial clusters: The case of an iron and steel cluster in northern Vietnam“, Journal of Comparative Economics, Vol. 37(4): 568-81. 
Ninkovic, Jasminka, 2009-02-15 "What Determines Export Success in Labor-Intensive Goods?", Paper presented at the annual meeting of the ISA's 50th ANNUAL CONVENTION “EXPLORING THE PAST, ANTICIPATING THE FUTURE”, New York Marriott Marquis, NEW YORK CITY, NY, USA Online <PDF>. Online:

http://www.allacademic.com/meta/p312839 index.html, accessed on 2011-03- 07.

Salvatore, D., and Hatcher, Thomas. 1991. "Inward Oriented and Outward Oriented Trade Strategies", The Journal of Development Studies, Vol. 27(3): 7-25.

Schmitz, Hubert and Knorringa, Peter. 2000. "Learning from Global Buyers", Journal of Development Studies, Vol. 37(2): 177-205.

Schmitz, Hubert and Nadvi, Khalid (1999). "Clustering and Industrialization: Introduction", World Development 27(9), 1503-14.

Sonobe, Tetsushi and Otsuka, Keijiro. 2011. Cluster-Based Industrial Development: A Comparative Study of Asia and Africa. Basingstoke: Palgrave McMillan.

Sud, Hari (2005). 'The FDI underachiever - India', Paper No. 1462, South Asia Analysis Group, Noida, India.

Trefler, Daniel and Zhu, Susan Chun. 2000. "Beyond the Algebra of Explanation: HOV for the Technology Age". The American Economic Review. Paper and Proceedings of the One Hundred Twelfth Annual Meeting of the American Economic Association", Vol. 90(2): 145-9.

Tybout, James R. 2000. "Manufacturing Firms in Developing Countries: How Well do They Do and Why?", Journal of Economic Literature, Vol., 38, March: 11-44

U.S. Department of Commerce. 2010. Office of Textiles and Apparel (OTEXA). Washington, D.C: International Trade Administration. Online: http://otexa.ita.doc.gov/msrpoint.htm, accessed on January 30, 2011.

Vernon, Raymond. 1966. "International Investment and International Trade in Product Cycle", Quarterly Journal of Economics, Vol. 80. No. 2: 190-207.

Wooldridge, Jeffery M. 2009. Introductory Econometrics A Modern Approach $4^{\text {th }}$ Edition. SouthWestern: Cengage Learning: 527-8.

World Bank. (2010), Global Monitoring Report 2010. http://web.worldbank.org/WBSITE/EXTERNAL/EXTDEC/EXTGLOBALMONITOR/EXT GLOMONREP2010/0, contentMDK:22522919 pagePK:64168445 piPK:64168309 theSite PK:6911226,00.html (accessed May 5, 2011).

World Bank. 2009. World Development Indicators 2009. CD-ROM Version. Washington D.C.: World Bank

World Bank. 2011. Infrastructure Database. Online: http://data.worldbank.org/topic/infrastructure, accessed on January 30, 2011.

World Trade Organization. 2010. Statistics Database. Online: http://stat.wto.org/StatisticalProgram/WSDBStatProgramHome.aspx?Language= $\underline{\text { E}}$, accessed on March 10, 2011.

Yamamura, Eiji, Sonobe, Tetsushi and Otsuka, Keijiro. 2003. "Human Capital, Cluster Formation and International Relocation: The Case of the Garment Industry in Japan 1968-98", Journal of Economic Geography, Vol.3(1): 37-56.

Zakim, Michael. 1999. "A Ready-made Business: The Birth of the Garment Industry in America", Business History Review, Vol. 73, Spring: 61-90. 
Table 1: Information on Garment and Textiles Exports by the Sampled Developing Countries in 2007 (per country average in the region)

\begin{tabular}{lcccc}
\hline Indicators & $\begin{array}{c}\text { South and } \\
\text { East Asia }\end{array}$ & $\begin{array}{c}\text { Central } \\
\text { Asia }\end{array}$ & $\begin{array}{c}\text { Sub- } \\
\text { Saharan } \\
\text { Africa }\end{array}$ & $\begin{array}{c}\text { Latin Americal } \\
\text { North Africa } \\
\text { \& Europe }\end{array}$ \\
\hline No of countries & 13 & 7 & 30 & 14 \\
Garment export (million USD) & 5440.0 & 86.4 & 17.9 & 752.0 \\
Textiles export (million USD) & 6080.0 & 347.0 & 13.1 & 181.0 \\
Share of textiles export in total export earnings (\%) & 9.5 & 1.5 & 0.03 & 1.1 \\
Share of garment export in total export earnings (\%) & 5.4 & 1.1 & 0.09 & 6.6 \\
\hline
\end{tabular}

Sources: Table A2 in the annexure

Table 2: Information on the Factor Endowment and Physical Infrastructure of the Sampled Developing Countries in 2007 (country average)

\begin{tabular}{|c|c|c|c|c|}
\hline Indicators & $\begin{array}{l}\text { South and } \\
\text { East Asia }\end{array}$ & $\begin{array}{c}\text { Central } \\
\text { Asia }\end{array}$ & $\begin{array}{l}\text { Sub- } \\
\text { Saharan } \\
\text { Africa }\end{array}$ & $\begin{array}{l}\text { Latin America/ } \\
\text { North Africa } \\
\text { \& Europe }\end{array}$ \\
\hline Gross fixed capital per worker (current USD equivalent) & 816.5 & 1545.5 & 475.4 & 1398.4 \\
\hline Arable land per worker (hectares) & 0.24 & 0.50 & 0.50 & 0.60 \\
\hline Total no. of workers (million) & 116.0 & 7.77 & 8.83 & 6.16 \\
\hline Electricity consumption per person (kilowatt hour ) & 637.1 & 1740.6 & 206.8 & 988.7 \\
\hline Internet user (per 100 people) & 7.4 & 13.9 & 3.0 & 12.8 \\
\hline Total road networks (1000 kilometers) & 623.9 & 58.7 & 42.1 & 37.7 \\
\hline
\end{tabular}

Sources: Table A2 in the annexure

Table 3: Information on Physical Infrastructure and Business Environment in the Sampled Developing Countries in 2007 by region (country average)

\begin{tabular}{lcccc}
\hline & $\begin{array}{c}\text { South and } \\
\text { East Asia }\end{array}$ & $\begin{array}{c}\text { Central } \\
\text { Asia }\end{array}$ & $\begin{array}{c}\text { Sub- } \\
\text { Saharan } \\
\text { Africa }\end{array}$ & $\begin{array}{c}\text { Latin Americal } \\
\text { North Africa } \\
\text { \& Europe }\end{array}$ \\
\hline Days required to start a business & 48.0 & 20.7 & 51.3 & 30.1 \\
\hline Inflation rate, consumer price (annual) & 6.5 & 9.2 & 7.2 & 6.9 \\
Currency exchange rate with US dollar & 1583.6 & 2098.0 & 712.4 & 343.7 \\
No. of landlocked countries & 2 & 3 & 8 & 3 \\
No. of lower-middle income countries & 10 & 5 & 8 & 15 \\
Distance to New York (kilometer) & 12925.9 & 9092.9 & 11242.3 & 6709.4 \\
Distance to Brussels (kilometer) & 9300.9 & 4938.2 & 5754.1 & 7392.9 \\
\hline
\end{tabular}

Sources: Various sources. See annexure 
Table 4: Determinants of Garments Export by the Developing Countries

\begin{tabular}{|c|c|c|c|c|}
\hline \multirow{3}{*}{$\begin{array}{c}\text { Estimation method } \\
\text { Dependent variable }\end{array}$} & \multicolumn{4}{|c|}{ Random effect Generalized Least Square Estimation } \\
\hline & \multicolumn{4}{|c|}{$\log ($ Export of garment) } \\
\hline & 2 & 3 & 4 & 5 \\
\hline $\log$ (Gross fixed capital per worker)t-1 & $\begin{array}{l}0.17^{\star \star} \\
(2.35)\end{array}$ & $\begin{array}{l}0.18^{\star \star} \\
(2.48)\end{array}$ & $\begin{array}{l}0.17^{\star \star} \\
(2.12)\end{array}$ & $\begin{array}{l}0.17^{\star *} \\
(2.27)\end{array}$ \\
\hline log (Arable land per worker) & $\begin{array}{c}0.12 \\
(0.21)\end{array}$ & $\begin{array}{c}0.09 \\
(0.16)\end{array}$ & $\begin{array}{c}0.09 \\
(0.15)\end{array}$ & $\begin{array}{c}0.07 \\
(0.13)\end{array}$ \\
\hline $\log$ (Total labor forces) & $\begin{array}{l}0.91^{*} \\
(1.74)\end{array}$ & $\begin{array}{l}0.97^{*} \\
(1.81)\end{array}$ & $\begin{array}{l}0.94^{\star} \\
(1.64)\end{array}$ & $\begin{array}{l}0.98^{\star} \\
(1.69)\end{array}$ \\
\hline log (Per capita electricity consumption) & $\begin{array}{l}0.84^{*} \\
(1.79)\end{array}$ & $\begin{array}{l}0.78^{\star} \\
(1.70)\end{array}$ & $\begin{array}{l}0.75^{\star} \\
(1.72)\end{array}$ & $\begin{array}{l}0.81^{*} \\
(1.92)\end{array}$ \\
\hline log (Days required to start a business) & $\begin{array}{l}-0.54^{\star *} \\
(-1.99)\end{array}$ & $\begin{array}{l}-0.59 * * \\
(-2.11)\end{array}$ & $\begin{array}{l}-0.59^{\star *} \\
(-2.06)\end{array}$ & $\begin{array}{l}-0.61^{\star *} \\
(-2.17)\end{array}$ \\
\hline Landlocked country dummy (yes=1) & $\begin{array}{l}-2.30^{\star \star *} \\
(-2.61)\end{array}$ & $\begin{array}{r}-2.39 \star \star \star \\
(-2.69)\end{array}$ & $\begin{array}{l}-2.40^{\star \star \star} \\
(-2.68)\end{array}$ & $\begin{array}{c}-2.36^{\star * *} \\
(-2.66)\end{array}$ \\
\hline Lower-middle income country dummy (yes=1) & $\begin{array}{l}-2.06^{\star *} \\
(-1.97)\end{array}$ & $\begin{array}{l}-1.81^{*} \\
(-1.67)\end{array}$ & $\begin{array}{l}-1.87^{*} \\
(-1.65)\end{array}$ & $\begin{array}{l}-1.86^{*} \\
(-1.67)\end{array}$ \\
\hline Central Asian country dummy & $\begin{array}{l}-2.10 \\
(-0.91)\end{array}$ & $\begin{array}{l}-2.26 \\
(-1.18)\end{array}$ & $\begin{array}{l}-2.31 \\
(-1.20)\end{array}$ & $\begin{array}{c}-2.39 \\
(-1.27)\end{array}$ \\
\hline Sub-Saharan Africa country dummy & $\begin{array}{l}-4.46^{\star \star *} \\
(-3.06)\end{array}$ & $\begin{array}{l}-4.45^{\star \star \star} \\
(-3.07)\end{array}$ & $\begin{array}{c}-4.45^{\star \star \star} \\
(-3.08)\end{array}$ & $\begin{array}{l}-4.38^{\star \star *} \\
(-3.07)\end{array}$ \\
\hline \multirow[t]{2}{*}{ Latin America and Other country dummy } & 0.28 & 0.21 & 0.19 & 0.12 \\
\hline & $(0.17)$ & $(0.13)$ & $(0.12)$ & $(0.08)$ \\
\hline Year 2005 dummy & $\begin{array}{l}-0.24 \\
(-1.07)\end{array}$ & $\begin{array}{c}0.46 \\
(1.42)\end{array}$ & $\begin{array}{l}-0.30 \\
(-1.58)\end{array}$ & $\begin{array}{l}-0.29^{\star} \\
(-1.68)\end{array}$ \\
\hline Year 2006 dummy & $\begin{array}{l}-0.37 \\
(-1.40)\end{array}$ & $\begin{array}{c}0.19 \\
(0.92)\end{array}$ & $\begin{array}{l}-0.45^{\star *} \\
(-2.28)\end{array}$ & $\begin{array}{l}-0.46^{\star *} \\
(-2.45)\end{array}$ \\
\hline Year 2007 dummy & $\begin{array}{c}-0.43 \\
(-1.32)\end{array}$ & $\begin{array}{c}0.06 \\
(0.31)\end{array}$ & $\begin{array}{l}-0.51^{\star *} \\
(-1.96)\end{array}$ & $\begin{array}{l}-0.53^{\star \star} \\
(-2.12)\end{array}$ \\
\hline log (Total road networks) & $\begin{array}{c}0.18 \\
(0.32)\end{array}$ & $\begin{array}{c}0.11 \\
(0.17)\end{array}$ & $\begin{array}{c}0.13 \\
(0.20)\end{array}$ & $\begin{array}{c}0.08 \\
(0.12)\end{array}$ \\
\hline $\log$ (Distance to USA) & $\begin{array}{l}-0.55 \\
(-0.54)\end{array}$ & $\begin{array}{c}-0.62 \\
(-0.69)\end{array}$ & $\begin{array}{c}-0.62 \\
(-0.69)\end{array}$ & $\begin{array}{c}-0.59 \\
(-0.66)\end{array}$ \\
\hline log (Distance to EU) & $\begin{array}{l}-1.07 \\
(-1.47)\end{array}$ & $\begin{array}{c}-1.11 \\
(-1.62)\end{array}$ & $\begin{array}{l}-1.11^{*} \\
(-1.65)\end{array}$ & $\begin{array}{l}-1.05 \\
(-1.59)\end{array}$ \\
\hline log (Annual inflation rate) & $\begin{array}{l}0.06 \\
(0.31)\end{array}$ & $\begin{array}{c}0.07 \\
(0.38)\end{array}$ & $\begin{array}{c}0.08 \\
(0.42)\end{array}$ & \\
\hline log (Internet users per 100 people) & $\begin{array}{l}-0.15 \\
(-0.32)\end{array}$ & $\begin{array}{c}-0.08 \\
(-0.19)\end{array}$ & & \\
\hline \multirow[t]{2}{*}{ log (Currency exchange rate in terms of US dollar) } & -0.06 & & & \\
\hline & $(-0.34)$ & & & \\
\hline Constant & $\begin{array}{l}15.64 \\
(1.15) \\
\end{array}$ & $\begin{array}{l}15.85 \\
(1.19) \\
\end{array}$ & $\begin{array}{l}16.56 \\
(1.24) \\
\end{array}$ & $\begin{array}{l}15.47 \\
(1.19)\end{array}$ \\
\hline$N$ & 227 & 235 & 238 & 244 \\
\hline No. of countries & 63 & 65 & 65 & 65 \\
\hline R squared overall & 0.67 & 0.67 & 0.67 & 0.67 \\
\hline Hausman test Fixed over Random effect: $\chi^{2}$ & 4.06 & 4.87 & 4.53 & 4.46 \\
\hline $\operatorname{Prob}>\chi^{2}$ & 0.97 & 0.90 & 0.87 & 0.88 \\
\hline Test of endogenity of per capita electricity variable & $\begin{array}{l}-0.38 \\
(0.71)\end{array}$ & $\begin{array}{c}-0.13 \\
(0.90)\end{array}$ & $\begin{array}{l}-0.12 \\
(0.90)\end{array}$ & $\begin{array}{l}-0.28 \\
(0.78\end{array}$ \\
\hline
\end{tabular}

Notes: Numbers in parentheses are z-statistics calculated based on standard errors corrected for clustering of observation at the country level, *, ** and *** indicate significance at the 10, 5 and 1 percent levels, respectively. 
Figure 1: Relationship between Garment Export and Per Capita Income $\ln$ (Garment export)

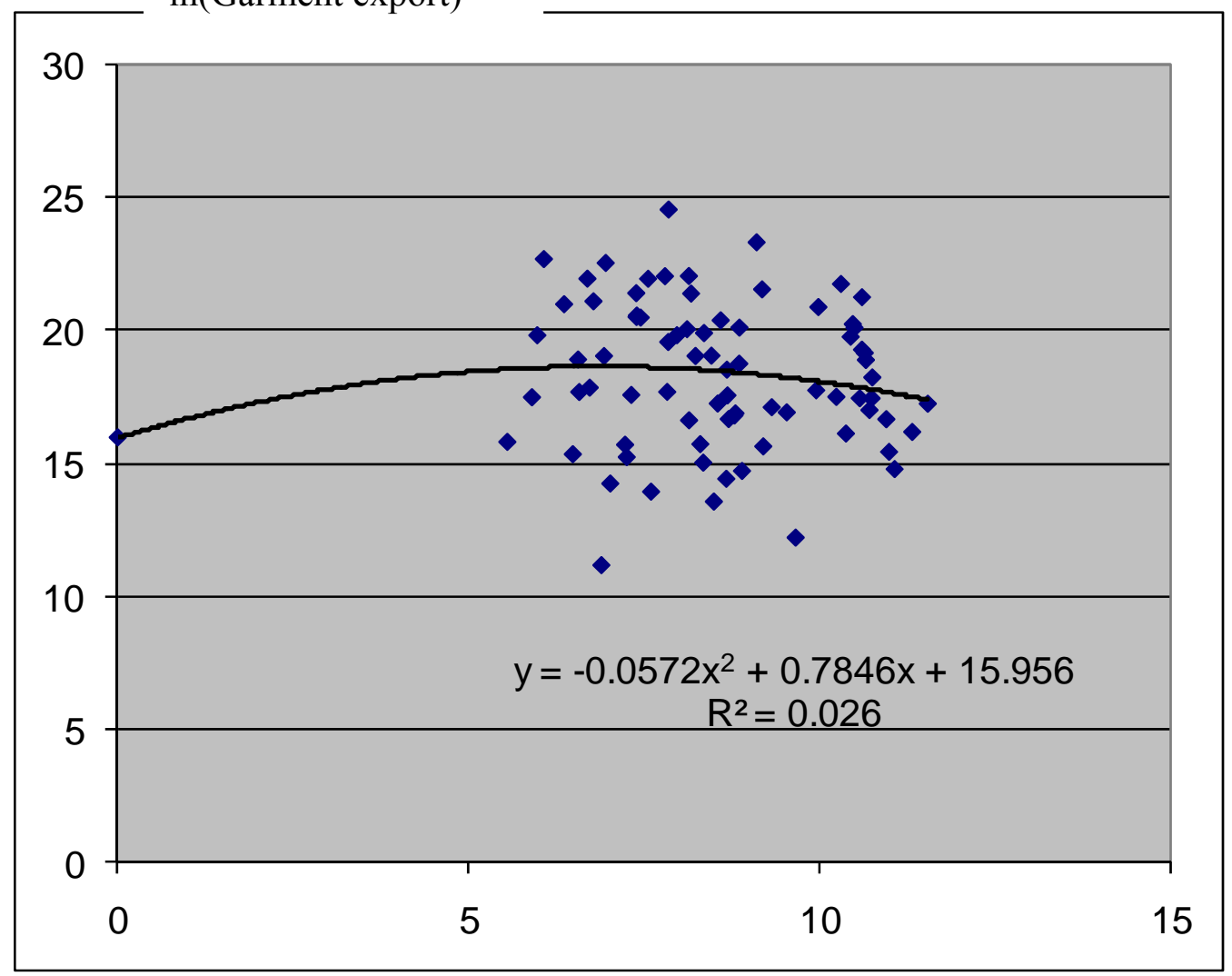


Annexure

Table A1: Name of the Sampled Countries by Region

\begin{tabular}{|c|c|c|c|}
\hline South and East Asia & Central Asia & Sub-Saharan Africa & Europe, Latin America and Others \\
\hline & & Angola & Albania \\
\hline Bangladesh & Georgia & Cameroon & Bolivia \\
\hline Bhutan & Iran, Islamic Rep. & Cape Verde & Ecuador \\
\hline Cambodia & Jordan & Central African Republic & Egypt, Arab Rep. \\
\hline China & Kyrgyz Republic & Chad & El Salvador \\
\hline India & Mongolia & Comoros & Guatemala \\
\hline Nepal & Syrian Arab Republic & Congo, Dem. Rep. & Honduras \\
\hline Pakistan & Uzbekistan & Congo, Rep. & Moldova \\
\hline Papua New Guinea & & Cote d'Ivoire & Morocco \\
\hline Philippines & & Eritrea & Nicaragua \\
\hline Solomon Islands & & Ethiopia & Paraguay \\
\hline Sri Lanka & & Gambia, The & Tonga \\
\hline Thailand & & Ghana & Tunisia \\
\hline \multirow[t]{17}{*}{ Vietnam } & & Guinea & Ukraine \\
\hline & & Guinea-Bissau & Vanuatu \\
\hline & & Kenya & \\
\hline & & Madagascar & \\
\hline & & Malawi & \\
\hline & & Mali & \\
\hline & & Mauritania & \\
\hline & & Mozambique & \\
\hline & & Nigeria & \\
\hline & & Rwanda & \\
\hline & & Senegal & \\
\hline & & Sierra Leone & \\
\hline & & Sudan & \\
\hline & & Swaziland & \\
\hline & & Tanzania & \\
\hline & & Uganda & \\
\hline & & Zambia & \\
\hline
\end{tabular}




\section{Table A2: Data sources}

\section{Garment Export:}

Export to EU: Online:

http://epp.eurostat.ec.europa.eu/portal/page/portal/eurostat/home.

Export to USA: Online: http://otexa.ita.doc.gov/msrpoint.htm

\section{Textiles Export:}

http://stat.wto.org/StatisticalProgram/WSDBStatProgramSeries.aspx?Language=E

Data on gross fixed capital, labor force, days required to start a business, electricity consumption per capita, total road networks, annual inflation rate:

http://databank.worldbank.org/ddp/home.do?Step=2\&id=4\&hActiveDimensionld=WDI Series http://data.worldbank.org/topic/infrastructure

Data on arable land:

Online: http://faostat.fao.org/site/377/default.aspx\#ancor

Information on landlocked country:

Online: http://www.wisegeek.com/what-countries-are-landlocked.htm

\section{Distance to EU and USA calculated from:}

http://www.distancefromto.net/distance-from/Vietnam/to/Belgium 
Table A3: Correlation Matrix Among Garment \& Textiles Exports and Factor Endowment \& Infrastructure Variable in 2007

\begin{tabular}{|c|c|c|c|c|c|c|c|c|}
\hline & GAREX & TEX & FCAP & ARAL & $L A B$ & ELEC & INET & $\mathrm{ROAD}$ \\
\hline GAREX & $\begin{array}{l}1.00 \\
{[65]}\end{array}$ & & & & & & & \\
\hline TEX & $\begin{array}{c}0.98^{* \star *} \\
(0.00) \\
{[55]}\end{array}$ & $\begin{array}{c}1.0 \\
{[55]}\end{array}$ & & & & & & \\
\hline FCAP & $\begin{array}{c}0.97^{\star * \star} \\
(0.00) \\
{[64]}\end{array}$ & $\begin{array}{c}0.98^{\star * \star} \\
(0.00) \\
{[54]}\end{array}$ & $\begin{array}{c}1.00 \\
64\end{array}$ & & & & & \\
\hline ARAL & $\begin{array}{c}0.62^{2 * \star} \\
(0.00) \\
{[65]}\end{array}$ & $\begin{array}{c}0.66^{\star \star \star} \\
(0.00) \\
{[55]}\end{array}$ & $\begin{array}{c}0.76^{\star \star \star} \\
(0.00) \\
{[64]}\end{array}$ & $\begin{array}{c}1.00 \\
65\end{array}$ & & & & \\
\hline LAB & $\begin{array}{c}0.91^{\star \star \star} \\
(0.00) \\
{[65]}\end{array}$ & $\begin{array}{c}0.93^{\star \star \star} \\
(0.00) \\
{[55]}\end{array}$ & $\begin{array}{c}0.97^{\star \star \star} \\
(0.00) \\
{[64]}\end{array}$ & $\begin{array}{c}0.87^{\star * *} \\
(0.00) \\
{[65]}\end{array}$ & $\begin{array}{l}1.00 \\
{[65]}\end{array}$ & & & \\
\hline ELEC & $\begin{array}{c}0.30^{\star \star \star} \\
(0.01) \\
{[65]}\end{array}$ & $\begin{array}{c}0.31^{\star *} \\
(0.02) \\
{[55]}\end{array}$ & $\begin{array}{c}0.32^{\star \star *} \\
(0.01) \\
{[64]}\end{array}$ & $\begin{array}{c}0.23^{*} \\
(0.07) \\
{[65]}\end{array}$ & $\begin{array}{c}0.26^{\star \star} \\
(0.04) \\
{[65]}\end{array}$ & $\begin{array}{l}1.00 \\
{[65]}\end{array}$ & & \\
\hline INET & $\begin{array}{c}0.23^{*} \\
(0.07) \\
{[62]}\end{array}$ & $\begin{array}{c}0.21 \\
(0.13) \\
{[52]}\end{array}$ & $\begin{array}{c}0.22^{\star} \\
(0.09) \\
{[61]}\end{array}$ & $\begin{array}{c}0.19 \\
(0.15) \\
{[62]}\end{array}$ & $\begin{array}{c}0.18 \\
(0.17) \\
{[62]}\end{array}$ & $\begin{array}{c}0.77^{* * \star} \\
(0.00) \\
{[62]}\end{array}$ & $\begin{array}{l}1.00 \\
{[62]}\end{array}$ & \\
\hline ROAD & $\begin{array}{c}0.80^{\star \star \star} \\
(0.00) \\
{[65]}\end{array}$ & $\begin{array}{c}0.83^{\star \star \star} \\
(0.00) \\
{[55]}\end{array}$ & $\begin{array}{c}0.90^{* * *} \\
(0.00) \\
{[64]}\end{array}$ & $\begin{array}{c}0.95^{\star \star \star} \\
(0.00) \\
{[65]}\end{array}$ & $\begin{array}{c}0.97^{\star \star \star} \\
(0.00) \\
{[65]}\end{array}$ & $\begin{array}{c}0.23^{*} \\
(0.06) \\
{[65]}\end{array}$ & $\begin{array}{c}0.16 \\
(0.21) \\
{[62]}\end{array}$ & $\begin{array}{l}1.00 \\
{[65]}\end{array}$ \\
\hline
\end{tabular}

Variables in ( ) are p-values and variables in [ ] are number of observations of the corresponding variable. ${ }^{* \star}$, ${ }^{* \star}$ and * represents significance at the $1 \%, 5 \%$ and $10 \%$ levels, respectively

GAREX=garment export earnings, TEX=textiles export earnings, FCAP= gross fixed capital, ARAL= arable land, $L A B=t o t a l$ labor force, ELEC= electricity consumption per capita, INET= nternet users per 100 people, ROAD= total road networks. 
Table A4: Correlation Matrix among Garment and Textiles Exports and Some Macroeconomic and Time Invariant Variables in 2007.

\begin{tabular}{|c|c|c|c|c|c|c|c|c|c|}
\hline & GAREX & TEX & TSTBUSI & INFLA & XRATE & LALOC & LMIC & DISUSA & DISEU \\
\hline GAREX & $\begin{array}{l}1.00 \\
{[65]}\end{array}$ & & & & & & & & \\
\hline TEX & $\begin{array}{c}0.98^{\star \star \star} \\
(0.00) \\
{[55]}\end{array}$ & $\begin{array}{l}1.00 \\
{[55]}\end{array}$ & & & & & & & \\
\hline TSTBUSI & $\begin{array}{c}-0.04 \\
(0.78) \\
{[65]}\end{array}$ & $\begin{array}{c}-0.02 \\
(0.89) \\
{[55]}\end{array}$ & $\begin{array}{l}1.00 \\
65.00\end{array}$ & & & & & & \\
\hline INFLA & $\begin{array}{c}-0.07 \\
(0.57) \\
{[60]}\end{array}$ & $\begin{array}{c}-0.10 \\
(0.48) \\
{[51]}\end{array}$ & $\begin{array}{c}-0.02 \\
(0.89) \\
{[60]}\end{array}$ & $\begin{array}{l}1.00 \\
{[60]}\end{array}$ & & & & & \\
\hline XRATE & $\begin{array}{c}-0.01 \\
(0.91) \\
{[63]}\end{array}$ & $\begin{array}{c}-0.04 \\
(0.75) \\
{[54]}\end{array}$ & $\begin{array}{c}0.00 \\
(1.00) \\
{[63]}\end{array}$ & $\begin{array}{c}0.21 \\
(0.12) \\
{[59]}\end{array}$ & $\begin{array}{l}1.00 \\
{[63]}\end{array}$ & & & & \\
\hline LALOC & $\begin{array}{c}-0.12 \\
(0.33) \\
{[65]}\end{array}$ & $\begin{array}{c}-0.12 \\
(0.40) \\
{[55]}\end{array}$ & $\begin{array}{c}-0.18 \\
(0.14) \\
{[65]}\end{array}$ & $\begin{array}{c}-0.05 \\
(0.69) \\
{[60]}\end{array}$ & $\begin{array}{c}0.00 \\
(0.99) \\
{[63]}\end{array}$ & $\begin{array}{l}1.00 \\
{[65]}\end{array}$ & & & \\
\hline LMIC & $\begin{array}{c}0.13 \\
(0.32) \\
{[65]}\end{array}$ & $\begin{array}{c}0.15 \\
(0.27) \\
{[55]}\end{array}$ & $\begin{array}{c}-0.19 \\
(0.13) \\
{[65]}\end{array}$ & $\begin{array}{c}-0.14 \\
(0.29) \\
{[60]}\end{array}$ & $\begin{array}{c}-0.20 \\
(0.12) \\
{[63]}\end{array}$ & $\begin{array}{c}-0.30 \\
(0.02) \\
{[65]}\end{array}$ & $\begin{array}{l}1.00 \\
{[65]}\end{array}$ & & \\
\hline DISUSA & $\begin{array}{c}0.06 \\
(0.61) \\
{[65]}\end{array}$ & $\begin{array}{c}0.08 \\
(0.55) \\
{[55]}\end{array}$ & $\begin{array}{c}0.12 \\
(0.33) \\
{[65]}\end{array}$ & $\begin{array}{c}0.09 \\
(0.50) \\
{[60]}\end{array}$ & $\begin{array}{c}0.15 \\
(0.23) \\
{[63]}\end{array}$ & $\begin{array}{c}0.13 \\
(0.32) \\
{[65]}\end{array}$ & $\begin{array}{c}-0.32 \\
(0.01) \\
{[65]}\end{array}$ & $\begin{array}{l}1.00 \\
{[65]}\end{array}$ & \\
\hline DISEU & $\begin{array}{c}0.10 \\
(0.43) \\
{[65]}\end{array}$ & $\begin{array}{c}0.13 \\
(0.33) \\
{[55]}\end{array}$ & $\begin{array}{c}0.06 \\
(0.63) \\
{[65]}\end{array}$ & $\begin{array}{c}-0.03 \\
(0.84) \\
{[60]}\end{array}$ & $\begin{array}{c}0.06 \\
(0.63) \\
{[63]}\end{array}$ & $\begin{array}{c}-0.07 \\
(0.55) \\
{[65]}\end{array}$ & $\begin{array}{c}0.18 \\
(0.15) \\
{[65]}\end{array}$ & $\begin{array}{c}0.17 \\
(0.17) \\
{[65]}\end{array}$ & $\begin{array}{l}1.00 \\
{[65]}\end{array}$ \\
\hline
\end{tabular}

Variables in ( ) are p-values and variables in [] are number of observations of the corresponding variable. ${ }^{* \star}$, ${ }^{* \star}$ and * represents significance at the $1 \%, 5 \%$ and $10 \%$ levels, respectively

TSTBUSI= days required to start a new business, INFLA= consumer price inflation, XRATE= currency exchange rate with US dollar, LALOC= dummy for landlocked country, LIMC= dummy for lower-middle income country, DISUSA= distance to USA, DISEU= distance to EU. 